\title{
DESAIN KURIKULUM PAI DALAM MENAGKAL RADIKALISME DI SEKOLAH
}

\begin{abstract}
Afidatul Bariroh*
Abstrak: Paham radikalisme yang menguasai ideologi peserta didik menjadi perhatian khusus komponen-komponen sekolah untuk mendesain kembali kurikulum Pendidikan Agama Islam. Fenomena tindak kekerasan, tawuran antar sekolah, perkelahian antar pelajar sampai kepada pembunuhan antar pelajar menawarkan sistem pendidikan multikultural dalam dunia pendidikan untuk menjadi solusi utama dalam indikasi internalisasi nilai-nilai untuk menghargai kelompok-kelompok lain dari berbagai macam etnik, gender, dan afiliasi budayanya. Berdasarkan hasil kajian yang penulis lakukan, menjadi tanggung jawab besar guru PAI di sekolah dalam mencanangkan konsep nilai yang ada pada pendidikan multikultural sehingga peserta didik mampu belajar hidup dari perbedaan, membangun sikap saling percaya, memelihara sikap saling penegertian, mengutamakan sikap saling menghargai, terbuka dalam berpikir, dan rekonsiliasi nirkekerasan.
\end{abstract}

Kata Kunci: Desain, Kurikulum PAI, Radikalisme.

\section{Pendahuluan}

aat ini dunia digoncangkan oleh maraknya aksi kekerasan yang krusial, maka dari itu dibutuhkan perhatian yang serius dari berbagai pihak agar tidak memiliki potensi dalam memecah belah persatuan dan kesatuan bangsa yang akan membawa kemunduran terhadap proses tumbuhnya demokratisasi dalam kehidupan berbangsa dan bernegara. Bila kita amati kembali, agama seharusnya mampu mengarahkan ummat manusia untuk selalu menegakkan perdamaian dan meningkatkan kesejahteraan hidup bagi seluruh ummat di dunia. Namun, realita yang ada agama justru

* Pasca Sarjana Jurusan PAI di Universitas Nurul Jadid Paiton Probolinggo. Email: Afidatulbariroh@gmail.com 
menjadi tonggak pemicu terjadinya berbagai kekerasan dan kehancuran kehidupan ummat manusia. Hal tersebut menunjukkan bahwa pendidikan agama baik di sekolah formal maupun sekolah agama lebih bercorak eksklusive, yaitu agama diajarkan dengan cara fanatik dan moderat sehingga yang terjadi ialah menafikan hak hidup agama lain, seakan-akan hanya agama yang dianutnya yang paling benar dan mempunyai hak hidup, sementara agama yang lain dianggapnya sesat.

Ad-dinul Islam yang di bawa oleh Nabi Muhammad adalah agama yang mengajarkan perdamaian dan keselamatan hidup di dunia dan Akhirat. Secara literal, Islam mampu menerima apa yang diberikan Tuhan dan cinta akan adanya kedamaian. Kedamaian dalam Islam berlandaskan pada kondisi batin yang terjadi pada individu seorang muslim, yang selalu berusaha memahami dan menjalankan kehendak Tuhan. Namun perjalanan hidup seseorang tidak akan jauh dari berbagai permasalahan yang dihadapi. Hal ini memiliki pengaruh terhadap pemahaman dan pengamalan agama. Yang terkadang menarik dan mendorong pada ujung ekstrimisme karena menyangkut keyakinan dan nilai-nilai yang ada di dalamnya (Universitas et al., 2017).Nabi Muhammad SAW tidak hanya diutus kepada umat tertentu saja, melainkan terhadap seluruh umat di muka bumi. Allah SWT menegaskan dalam firman-Nya surat Saba' ayat 28 (Roscahyo \& Prijati, 2013):

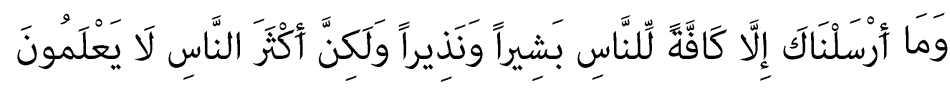

"Dan Kami tidak mengutus kamu, melainkan kepada umat manusia selurubnya sebagai pembawa berita gembira dan sebagai pemberi peringatan, tetapi kebanyakan manusia tiada mengetahui".

Meskipun pemerintah telah mencanangkan berbagai bentuk peraturan dan undang-undang yang mengatur tata kehidupan beragama agar terjadi harmonisasi antar umat, namun sepertinya radikalisme atas nama agama tidak kian henti, justru sebaliknya kian hari kian bertambah dengan berbagai bentuk, baik itu penganiyaan, pembakaran, pengeboman tempat ibadah, penodaan ajaran dan 
keyakinan agama, serta penghinaan terhadap keyakinan agama atau pemahaman ajaran orang lain.

Banyak diketahui fenomena kekerasan atasa nama agama banyak di dukung oleh kalangan peserta didik. Mereka yang memiliki misi untuk menerapkan amar ma'ruf nabi munkar namun, menggunakan tindakan yang tidak tepat, seperti halnya ikut serta dalam aksi-aksi menutup tempat-tempat yang dianggapnya sumber dari perbuatan maksiat dengan menguunakan aksi teror dan alhasil nyawa-nyawa tak bersalahpun ikut terancam.

Memandang Kondisi pendidikan di Indonesia termasuk pendidikan Islamnya tidak memadai lagi untuk masyarakat Indonesia yang plural dan multikultural. Oleh karena itu, perlu dilakukan transformasi paradigma pendidikan di Indonesia. Adapun paradigma pendidikan yang ditawarkan adalah desain pendidikan agama Islam berbasis multikultural sebagai pengganti paradigma pendidikan yang monokultural. Tawaran tentang pendidikan multikultural yang sangat urgen mampu mendapat respon positif dari pihak umum. Mengingat penyelenggaraan pendidikan membutuhkan kurikulum, maka nilai-nilai multikultural harus diinternalisasikan dalam dasar perencanaan, implementasi, dan evaluasi kurikulum suatu lembaga pendidikan baik dalam bentuk sekolah, madrasah, maupun pesantren.

\section{Hakikat Kurikulum}

Kurikulum sebagaimana telah ditegaskan dalam pasal 1 ayat (19) Undang-Undang Nomor 20 Tahun 2003 diartikan sebagai seperangkat rencana dan pengaturan terkait tujuan, isi, dan bahan pelajaran serta berbagai cara yang digunakan sebagai pedoman dalam penyelengaraan kegiatan belajar menagajar dalam mencapai tujuan tertentu dalam Pendidikan (Katni, 2015). Crow and Crow mengatakan sebagaimana dikutip oleh Bakri Marzuki bahwa kurikulum selanjutnya telah menjadi suatu istilah yang digunakan untuk menunjukkan sejumlah mata pelajaran yang harus ditempuh dalam jenjang yang telah ditentukan untuk mencapai suatu tujuan akhir (Hasan Baharun, 2018), yaitu suatu gelar atau ijazah. Di dalam 
kurikulum tidak hanya memuat sejumlah mata pelajaran, tetapi termasuk pula segala bentuk usaha sekolah dalam keinginan mencapai tujuan, baik dilakukan di lingkungan sekolah maupun di luar sekolah(Marzuki, 2008)

Omar Muhammad berpendapat sebagaiamana dikutip oleh Muhammad Irsad bahwa kurikulum merupakan jalan yang terang yang ditempuh oleh pendidik atau guru latih seiring dengan peserta didik yang dilatihnya sehingga mampu mengembangkan pengetahuan, ketrampilan, dan sikap yang tumbuh pada diri mereka. Di dalam kurikulum tidak hanya sekedar berisi rencana bidang studi, melainkan semua yang mencakup secara nyata terjadi dalam proses pendidikan di sekolah. (Irsyad, 2016) Menelaah kembali fungsi kurikulum dalam pendidikanmerupakan alat yang digunakan untuk mencapai suatu pendidikan, terdapat bagian-bagian penting yang mampu menunjang dan mendukung operasinya dengan baik. Penyusunan Kurikulum di dalamnya harus memuat beberapa komponen yang meliputi (Nurmadiah, 2014):1) tujuan kurikulum 2) materi 3) metode 4) evaluasi.

Dalam konteks kurikulum pendidikan Islam terdapat seperangkat rencana, tujuan, isi dan bahan ajar yang digunakan pendidik untuk membimbing peserta didik dalam mencapai tujuan pendidikan Islam yang mencakup tiga aspek pokok yaitu: Keimanan (akidah), keislaman (syariah), dan ihsan (akhlak) yang memiliki pertatutan sempurna terhadap agama. Titik temu yang membedakan kurikulum pendidikan Islam dengan kurikulum secara umum ialah konsep yang terdapat dalam pendidikan Islam yang mengacu pada pembentukan insan kamil.

Al Syaibani berpendapat sebagaimana telah dikutip Khuzaimah bahwa terdapat ciri-ciri kurikulum Pendidikan Islam selalu berkaitan dengan al-Quran dan Hadist. Sebagaimana berikut (Khuzaimah, 2017):berpacu pada pengutamaan agama dan akhlak dalam berbagai tujuannya; cakupan kurikulum bersifat menyeluruh yang menggambarkan semangat pemikiran dan ajaran Islam dalam menjangkau seluruh aspek kehidupan; dan mempunyai keseimbangan yang relativ di dalam muatan keilmuannya. 
Dalam kurikulum pendidikan Islam ada beberapa hal yang harus dibenahi yaitu: Pendidikan sebaiknya diarahkan mengacu pada al Qur'an, sehingga ilmu yang didapatkan pada ilmu pengetahuan dan teknologi (context of discovery) bukan sekedar pembenahan hasil-hasil yang telah dicapai (context o justification). Pendidikan agama Islam sebaiknya mampu mengikuti perubahan sosial yang terjadi begitu cepat sehingga norma agama tetap digunakan secara konsisten dalam pengambilan sebuah keputusan. Materi pendidikan pada hakikatnya didasarkan atas tiga pilar utama yakni landasan aksiologis, epistemologis, dan ontologis. Pendidikan Islam diharapkan tidak hanya menyentuh ranah kognitif, tetapi juga harus menyentuh ranah afektif dan psikomotorik. Karena agama bukanlah sistem pengetahuan saja akan tetapi juga terdapat sistem normative dan tauhid. Sehingga tumbuhlah kemauan dan tekad untuk mengamalkan nilai ajaran agama. Agar tidak terjadi kesenjangan antara pengetahuan dan pengamalan. Sehingga yang diharapkan mampu membentuk pribadi bermoral. Banyak orang yang hanya mengetahui nilai-nilai ajaran agama, akan tetapi tingkah lakunya tidak relevan dengan pengetahuan yang dimiliki.

Berbagai kritik yang muncul tentang kelemahan PAI dan sekaligus merupakan kegagalan pelaksanaan PAI bisa jadi disebabkan karena terdapat kekeliruan dalam mentransfer sistem pengembangan kurikulum atau pembelajaran yang berkembang selama ini (Muali, Islam, \& Bali, 2018), yang sebenarnya eksperimennya bukan berasal dari pendidikan agama tetapi dari bidang studi lain, kemudian diadopsi begitu saja tanpa adanya proses penyaringan kembali. Untuk mengantisipasi masalah tersebut, maka perlu dicarikan model pengembangan kurikulum PAI dengan mendudukkan kembali kepada landasan filosofisnya.

\section{Asas dan Peranan Pengembangan kurikulum PAI}

Dalam pandangan modern kurikulum merupakan program pendidikan yang digunakan bahan ajar yang harus disajikan dalam proses kependidikan dan dipersiapkan oleh sekolah yang tidak hanya berupa bidang studi dan kegiatan belajar saja, akan tetapi terkait 
segala sesuatu yang menjadi elemen dan berpengaruh dalam perkembangan dan pembentukan karakter siswa sesuai dengan tujuan sebuah pendidikan yang diharapkan sehingga, dapat meningkatkan mutu kehidupannya yang dalam pelaksanaannya tidak hanya di sekolah akan tetapi diterapkan saat siswa berada di luar sekolah(Ramayulis, 2006).

Terdapat 3 faktor umum yang mendorong pengembangan kurikulum. yaitu (a) perubahan yang diinginkan masyarakat sehingga direalisasikan dalam bentuk perencanaan menuju sebuah perubahan perubahan yang cukup urgen dalam kurikulum dan sistem pendidikan, (b) perkembangan ilmu pengetahuan dan teknologi yang pesat, dan (c) pertambahan pesat penduduk dunia. Proses pengembangan kurikulum dijalankan karena (a) hasil penelitian dan pengembangan, (b) interaksi sosial, dan (c) metode pemecahan masalah(Kisbiyanto, 2016)

Pendidikan Islam yang berfalsafah terhadap al-Qur'an sebagai sumber utamanya, menjadikan al-Qur'an sebagai pedoman dalam penyusunan kurikulumnya. Di dalam Al-Quran dan Hadist ditemukan asas-asas yang dapat dijadikan pedoman untuk menyusun kurikulum. Asas tersebut adalah(Subhi, 2016);

\section{Taubid}

Sesuai dengan apa yang telah ada di al-Qur'an bahwa yang menjadi kurikulum inti Pendidikan Agama Islam adalah 'Tauhid/ keesaan' dan harus dimantapkan sebagai unsur pokok yang tidak dapat dirubah. Dalam al-Qur'an Allah menyatakan sifat tauhid sebagai berikut yang artinya:

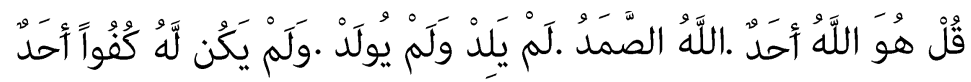

"Dia-lah Allah, yang Maha Esa. Allah adalah Tuhan yang bergantung kepada-Nya segala sesuatu. Dia tiada beranak dan tidak pula diperanakean, dan tidak ada seorangpun yang setara dengan Dia."(QS. Al-Ikhlas: 1-4). 
Iqro'

Kurikulum inti selanjutnya adalah perintah Allah kepada nabi Muhammad pertama kali yaitu untuk membaca ayat-ayat Allah yang meliputi 3 macam ayat, yaitu: Ayat Allah yang berdasarkan wahyu, Ayat Allah yang ada pada diri manusia, dan Ayat Allah yang terdapat di dalam semesta. Ketiga ayat tersebut terkandung dalam (QS. AlAlaq: 1-5):

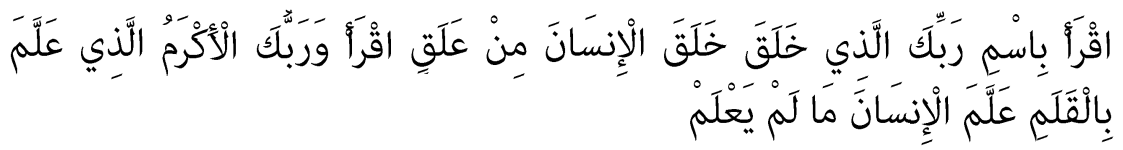

"Bacalab dengan (menyebut) nama Tuhanmu yang Menciptakan, Dia telah menciptakan manusia dari segumpal darah. Bacalah, dan Tubanmulah yang Maba pemurah, yang mengajar (manusia) dengan perantaran kalam. Dia mengajar kepada manusia apa yang tidak diketabuinya.

Pada dasarnya, pengembangan kurikulum sangat kompleks, karena banyak faktor yang terlibat di dalamnya Diketahui asas kurikulum secara umum harus didasarkan pada sejumlah asas yang digunakan, meliputi(Hasan, 2013):

1. Asas Religius (agama). Kurikulum yang akan dikembangkan dalam satuan pendidikan muatannya harus sesuai dengan hakikat penciptaan manusia. Maka pendidikan harus mampu mengembangkan secara integrative dalam pengembangan potensi jasmaniah dan rohaniah.

2. Asas Filosofis. Dengan filsafat sebagai pandangan hidup, mka menentukan mau dibawa kemana peserta didik itu. Filsafat juga mampu menetukan standard isi atau materi pelajaran yang hendak diberikan sesuai degan tujuan yang ingin dicapai, sistem nilai, dapat digunakan sebagai tolak ukur keberhasailan proses pendidikan.

3. Asas Psikologis. Kurikulum harus dirancang sesuai dengan ciriciri perkembangan anak didik seperti halnya kematangan bakat-bakat jasmani, intelektual, bahasa, emosi, kecakapan, perbedaan individual. Tugas utama yang sesungguhnya dari para pendidik adalah membantu perkembangan dan 
membentuk karakter peserta didik secara optimal supaya menjadi insan kamil. Apa saja yang harus dididikkan dan bagaimana cara mendidiknya, dibutuhkan peneyesuaian dengan pola-pola perkembangan anak.

4. Asas Sosiologis. Kurikulum diharapkan ikut serta dalam proses kemasyarakatan yang mampu menyesuaikan peserta didik dengan lingkungannya. Dalam menyusun kurikulum hendaknya berusaha untuk membahas problem-problem yang kerap terjadi pada lembaga pendidikan yang sesuai, dimulai dari gejala yang paling sederhana hingga yang paling komplek dengan cara pendekatan secara langsung melalui observasi, survei, sampai dengan penelitian yang serius dengan berlandaskan pengalaman dan teori-teori yang mendukung sehingga hasilnya dapat diarahkan dalam mewadahi kebutuhan masyarakatluas.

5. Asas Organisatoris. Hal ini berhubungan dengan masalah pengorganisasian kurikulum, yaitu tentang penyajian materi yang harus disampaiakan kepada peserta didik.

6. Asas IPTEK. Perkembangan IPTEK akan memberikan pengaruh terhadap individu, masyarakat, pengetahuan, kecakapan, sikap, minat, semangat, dan pola keseharian mereka.

Sebagai suatu komponen penting dalam pendidikan, setidaknya kurikulum memiliki tiga peranan, yaitu:

1. Peranan Konservatif. Sebagai sebuah lembaga, sekolah bertanggung jawab dalam mewariskan nilai-nilai budaya masyarakat kepada peserta didik. Sehingga ketika mereka kembali ke masyarakat mampu menjunjung tinggi dan berprilaku sesuai dengan norma-norma yang terdapat pada lingkungan masyarakat. Dengan adanya era globalisasi dikahwatirkan mampu menggerogoti budaya lokal. Melalui peran konsevatifnya kurikulum memiliki peran dalam menangkal berbagai pengaruh yang ingin merusak nilai-nilai luhur masayarakat, sehingga identitas masyarakat akan tetap terpelihara dengan baik. 
2. Peran Kritis atau evaluative. Nilai dan budaya yang ada harus tetap diseleksi dengan menyesuaikan perkembangan masyarakat. Dalam hal ini kurikulum berperan dalam menetukan hal-hal yang dianggap bermanfaat untuk kehidupan peserta didik.

3. Peran Kreatif. Lembaga sekolah memiliki tanggung jawab dalam mengembangkan hal-hal yang disesuaikan dengan perubahan zaman. Kurikulum diharapkan mampu menjawab setiap tantangan sesuai dengan perkembangan masyarakat yang cepat mengalami perubahan. Kurikulum diharapkan mampu membantu peserta didik dalam mengembangkan potensinya agar dapat berperan aktif dan senantiasa bergerak maju secara dinamis.

Dalam proses pengembangan kurikulum maka ketiganya harus berjalan beriringan. Kurikulum yang lebih menonjolkan konservatifnya, maka cenderung akan membuat pendidikan tertinggal oleh kemajuan zaman, sebaliknya jika kurikulum mengacu pada peran kreatifnya maka, dapat mengkikis nilai-nilai budaya masayarakat lokal pada umumnya.

\section{Pengembangan dan Desain kurikulum PAI Deradikalisme Di sekolah}

\section{Radikalisme Agama}

Islam merupakan agama yang mengikuti wahyu Ilahi yang diturunkan kepada para nabi dan rasul khususnya nabi akhir zaman Muhammad SAW guna sebagai pedoman hidup dan juga sebagai hukum/aturan Allah SWT yang dapat membimbing umat manusia ke jalan yang lurus(Baharun \& Mundiri, 2011), menuju kebahagiaan dunia maupun akhirat. Dalam realita yang ada banyak sikap berlebihan seseorang terhadap agama yang dianutnya sehingga menganggap orang lain yang tidak mengikuti ideologi yang diyakini sebaga agama yang sesat, dan menghalalkan berbagai cara untuk mempertahankan ideologinya, sekalipun itu dengan bentuk 
kekerasan dan menganggap itu sebagai bentuk jihad terhadap agama. Sehingga banyak nyawa tak bersalah terkena imbasnya.

Radikal dipahami sebagai aliran yang menginginkan pembaharuan dan perubahan sosial dengan menggunakan kekerasan atau drastis yang dilakukan dengan cara yang ekstrem. Radikalisme bisa dikelompokkan menjadi dua level, yaitu level pemikiran dan level aksi atau tindakan. Pada level pemikiran, radikalisme masih berbentuk wacana, konsep, dan gagasan yang kerap diperbincangkan, yang hakikatnya mendukung berbagai tindak kekerasan dalam tercapainya suatu tujuan. Adapun pada level aksi atau tindakan, radikalisme berada pada ranah sosial-politik dan agama. Pada ranah politik, faham ini digambarkan dengan adanya tindakan memaksakan kehendaknya dengan cara-cara yang inkonstitusional, bahkan bisa berbentuk tindakan mobilisasi masa untuk kepentingan politik tertentu dan berujung pada konflik sosial. Dalam bidang keagamaan, fenomena radikalisme agama terlihat dari munculnya tindakan-tindakan anarkis atas nama agama dari sekelompok orang terhadap kelompok pemeluk agama lain (eksternal) atau kelompok seagama (internal) yang berbeda dan menganggap kelompok lain sebagai golongan yang sesat(Munip, 2012). Pada dasarnya, kekerasan yang mengatasnamakan agama bisa terjadi dimana saja dan kapan saja. Hal itu berkembang jika agama hanya dipahami secara sempit, kaku, dan fanatik. Akhir-akhir ini banyak kejadian yang meresahkan warga setempat diantaranya maraknya aksi bom bunuh diri yang dilakukan oleh sebagian kelompok, berikut kutipan surat kabar yang penyusun dapatkan:

"Polri menangkap beberapa kelompok terorisme pasca adanya bom bunuh diri yang terjadi di Surabaya pada Mei 2018. Terdapat 260 orang terduga teroris yang diamankan. Dari total tersebut, sebagian besar sekiatr 170-an yang telah diduga tersangka. Polri tengah gencar menagkap oarang-orang yang telah diduga berafiliasi dengan kelompok teroris tanpa menggu adanya tindak pidana dari tindakan tersebut."

Tiga kecenderungan yang menjadi indikasi radikalisme. Pertama, radikalisme merupakan respons menolak terhadap kondisi yang sedang berlangsung, baik berupa asumsi, ide, lembaga, atau nilai-nilai 
tertentu. Kedua, radikalisme bisa meningkat menjadi upaya mengganti suatu asumsi, ide, lembaga, atau nilai-nilai tertentu. Kecenderungan seperti ini menunjukan bahwa di dalam radikalisme terkandung suatu asumsi, ide, lembaga, atau nilai-nilai tersendiri dengan menganggap bahwa nilai kelopoknya yang paling benar. Ketiga, radikalisme cenderung terjadi karena kuatnya keyakinan kaum radikalis akan kebenaran sistem ideologi yang dianut, sementara pada saat yang sama dibarengi dengan panafikan terhadap kebenaran sistem ideologi lain. Kuatnya keyakinan itulah yang memicu sikap fanatis yang pada gilirannya akan mengakibatkan munculnya sikap emosional di kalangan kaum radikalis dan keadaan saling menyalahkan dan menggap nilai yang berbeda dengan ideologi yang dianutnya sebuah pemikiran yang menyesatkan(Arif, 2017).

Sebagaimana dikutip Muhammad Thohir, Azyumardi Azra menjelaskan bahwa bahwa akar radikalisme itu setidaknya bersumber dari empat hal, yaitu(Thohir, 2015):

1. Pemahaman keagamaan sempit yang literal dan hanya memahami sepenggal-sepenggal terhadap ayat-ayat al-Qur'an. Pemahaman seperti itu hampir tidak memberikan ruang gerak bagi akomodasi dan kompromi dengan kelompok-kelompok muslim lain yang umumnya moderat, dan karena itu menjadi titik ledakan utama (mainstream) umat.

2. Pembacaan yang salah terhadap sejarah Islam yang dikombinasikan dengan idealisasi berlebihan terhadap Islam pada masa tertentu. Tidak jarang jika ditemukan kelompokkelompok yang saling menganggap sesat antar satu dan lainnya. Sehingga terjadilah justifikasi tindakan main hakim sendiri.

3. Argumentasi deprivasi politik, sosial dan ekonomi yang masih bertahan dalam masyarakat. Kelompok-kelompok ini dengan dogma eskatologis tertentu bahkan memandang dunia sudah menjelang akhir zaman dan kiamat; sekarang saatnya bertobat melalui pemimpin dan keyakinan yang diasumsi oleh kelompok mereka. Sehingga terjadi peningkatan konflik sosial dan kekerasan bernuansa intra dan antar agama; juga bahkan antar umat beragama dengan negara. 
4. Disorientasi dan dislokasi sosial budaya akibat globalisasi. Pada poin satu dan dua, radikalisme bermula pada level pemikiran (radical competence). Sedangkan pada level tiga dan empat, radikalisme bermula pada level tindakan dan situasi (radical performance).

\section{Desain Kurikulum PAI Berbasis Pendidikan Multikultural Anti} Radikalisme

Pendidikan Agama Islam (PAI) berbasis multicultural penting untuk ditawarkan dalam menanggulangi radikalisme di sekolah yang cenderung menganut sikap toleransi terhadap penganut agama lainnya dan berorientasi pada kesalehan individu. Jika dikaitkan dengan Pendidikan Agama Islam (PAI) Zakiuddin Baidhawi sebagaimana telah dikutip Kasinyo Harto bahwa ada tujuh konsep paradigmatic PAI berbasis multikultural, yaitu: mendidik peserta didik untuk(Harto, 2014);

1. Belajar Hidup dalam perbedaan. Ketika peserta didik mulai masuk sekolah, mereka terdiri dari latar belakang dan nilai-nilai yang berbeda-beda. Perbedaan nilai-nilai ini meniscayakan PAI tidak hanya berpijak pada paradigma learning to know, learning to do, learning to be, tetapi juga learning to live together. Sehingga menjadikan peserta didik mampu dalam mengembangkan sikap toleransi, empati, dan simpati yang menjadi syarat utama dalam meghadapi keragaman agama; klarifikasi nilai-nilai kehidupan bersama menurut perspektif agama-agama; pendewasaan emosional; kesetaraan dalam berpartisipasi; kontrak sosial baru dan saling menghargai antar umat beragama.

2. Membangun sikap saling percaya. PAI berbasis multikultural harus mengusung norma-norma kebaikan yang menjadi modal sosial dalam menumbuhkan rasa kepercayaan terhadap antar anggota masyarakat menanamkan sikap mutual trust atau saling pengertian antar agama, budaya dan etnik. Sehingga tidak ada kesan untuk membeda-bedakan ras atau golongan akan tetapi, dengan timbulnya berbagai macam perbedaan mampu menggerakkan rasa kebersamaan, keharmonisan, mobilitas ide, 
saling percaya dan saling ingin menguntungkan antara pihak satu dengan yang lainnya demi terwujudnya kemajuan bersama.

3. Memelihara saling pengertian. Saling pengertian dapat diartikan sebagai nilai-nilai mereka dan kita memiliki perbedaan, namun dari perbedaan tersebut diharapkan mampu untuk saling melengkapi serta berkontribusi terhadap keharmonisan dalam hubungan. Selain saling memahami PAI multikultural juga mendorong peserta didik mampu dengan lapang dada mampu menerima berbagai macam perbedaan di antara keragaman paham agama dan budaya masyarakat.

4. Menjunjung sikap saling menghargai. Bersikap menghargai terhadap semua orang dan menganggap setara. Yang pada realitasnya ajaran agama yang terkandung dalam PAI memang mengajarkan Muslim untuk menghormati dan menghargai sesama manusia. PAI multikultural diharapkan mampu menanamkan nilai kesadaran peserta didik bahwa kedamaian dan keharmonisan akan dicapai dalam kehidupan masyarakat jika sikap saling menghormati dan menghargai benar-benar diamalkan dalam kehidupan, bukan sikap saling merendahkan dan mencemooh terhadap golongan yang lain.

5. Terbuka dalam berpikir. Pada hal ini peserta didik di dorong untuk membuka diri terhadap kenyataan hidup yang beragam, khususnya dalam hal pemahaman agama. Peserta didik perlu disiapkan untuk berhadapan dengan model pemahaman agama yang berbeda dari apa yang diajarkan selama ini.

6. Resolusi konflik dan rekonsiliasi Nir Kekerasan. Menjadi tanggung jawab besar bagi PAI untuk mengarahkan peserta didik menjadi sosok yang dengan mudah mampu memaafkan kesalahan orang lain, meskipun tahu bahwa pendekatan hukum juga dapat dilakukan. Akan tetapi memeberi maaf jauh lebih mulia.

Pendidikan Multikultural paling tidak mengandung tiga hal yaitu

(1) mampu dan sadar akan pentingnya nilai keragaman budaya, (2) usaha dalam pembaharuan sistem pendidikan dan (3) proses dalam pendidikan multikultural, perbedaan yang ada di lingkungan sekolah 
tidaklah menjadi kendala dalam mendapatkan kesempatan belajar. Perbedaan yang ada merupakan hakikat atau sebuah kepastian adanya, namun perbedaan itu harus diterima secara wajar dan bukan menjadi sumber dari timbulnya persengketaan. Artinya perbedaan itu perlu kita terima sebagai bentuk kewajaran dan menerapkan sikap toleransi agar kita mampu hidup berdampingan secara damai tanpa saling membeda-bedakan antar kelompok satu dengan yang lainnya(Deny Setiawan, 2016).

Dalam konteks pedidikan multikultural terdapat tiga konsep yang menjadi penunjangnya meliputi: demokrasi, persamaan, kebebasan dan pluralisme. Namun, dalam rangka penerapan multikulturalisme, demokrasi yang diinginkan oleh Islam adalah demokrasi yang mempertemukan antara kepentingan individu dan sosial, antara nilai-nilai yang diyakini datang dari Tuhan dan nilainilai yang berasal dari manusia dalam hal ini Islam menyebutnya dengan shura bukan demokrasi liberal yang berbasis kekerasan seperti dunia Barat (Baharun \& Awwaliyah, 2017). Sebagaimana dijelaskan dalam Al-Qur'an surah Al-Syura ayat 38 sebagi berikut:

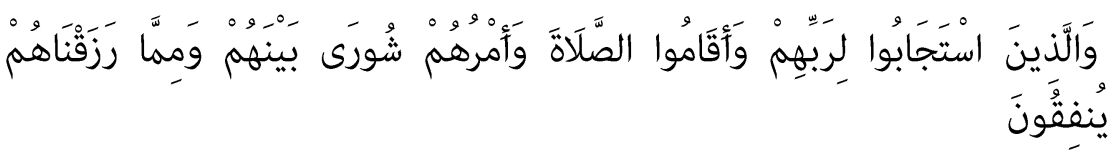

'Dan (bagi) orang-orang yang menerima (mematubi) seruan Tubannya dan mendirikan shalat, sedang urusan mereka (diputuskan) dengan musyawarat antara mereka; dan mereka menafkahkan sebagian dari reqki yang Kami berikan kepada mereka".

Konsep yang dikehendaki oleh pendidikan multicultural adalah adalah mencoba menggabungkan konsep liberal dengan egalitarian. Kaum egalitarian berpendapat bahwa semua orang harus diperlakukan sama dalam segala hal, karena mereka memang sama. Sehingga timbul konsep dalam menghapus hukum dan hak-hak istimewa yang tidak dibenarkan, yang hanya menyediakan posisiposisi sosial, ekonomi, dan politik tertentu. Para tokoh ilmuwan menerima konsep ini atas dasar Al-Qur'an surah Al-Hujurat ayat 13: 


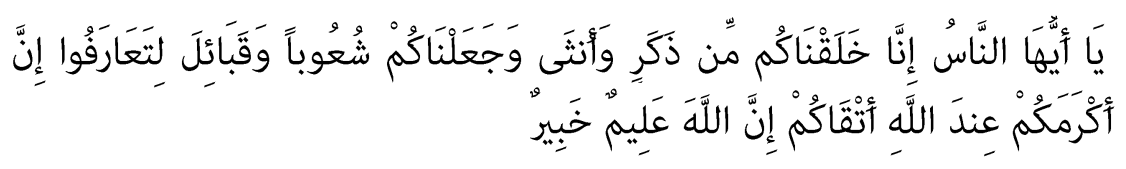

"Hai manusia, Sesunggubnya Kami menciptakan kamu dari seorang lakilaki dan seorang perempuan dan menjadikan kamu berbangsa-bangsa dan bersuku-suku supaya kamu saling kenal-mengenal. Sesunggubnya orang yang paling mulia diantara kamu disisi Allab ialah orang yang paling taqwa diantara kamu. Sesunggubnya Allab Maha mengetabui lagi Maha Mengenal".

Berdasarkan ayat tersebut, dapat dipahami bahwasannya Tuhan menciptkan manusia untuk berpasang-pasangan, walaupun realita yang ada terdiri dari bangsa, ras, agama, dan kulit yang berbeda-beda namun persatuan dan kesatuan tetaplah menjadi acuan utama,semua makhluk Tuhan bersaudara serta memiliki hak dan kewajiban yang sama di hadapan Tuhan.

Di sekolah pendidikan multikultural dapat diselenggarakan melalui berbagai macam pendekatan. Adapun pendekatan yang mungkin dapat dilakukan dalam penyelenggaraan pendidikan multikultural adalah pendekatan historis, pendekatan sosiologis, pendekatan kultural, pendekatan psikologis, pendekatan estetik, dan pendekatan berperspektif gender. Pendekatan historis, yakni materi pendidikan direfleksikan dengan melihat kembali peristiwa sejarah pada masa lampau. Melalui pendekatan historis, materi yang diajarkan dapat dianalisa secara kritis. Pendekatan sosiologis, melalui pendekatan ini materi pembelajaran menjadi lebih aktual, bukan karena dibuat-buat melainkan karena senantiasa mengikuti perkembangan zaman (Islam, Baharun, Muali, Ghufron, \& Bali, 2018). Pendekatan kultural, melalui pendekatan ini pendidik melihat manakah tradisi otentik dan mana yang bukan. Pendekatan psikologis, dalam hal ini sebaiknya pendidik memperhatikan psikologis seseorang secara tersendiri dan mandiri. Pendekatan estetik, yang mengajarkan pendidik untuk berlaku sopan, santun, damai, ramah, dan mencintai keindahan. Pendekatan berperspektif gender, yakni pendekatan yang menyadarkan para pendidik untuk tidak membedakan jenis kelamin, karena perbedaan kelamin 
bukanlah hal yang menhalangi seseorang untuk tetap menuju kesuksesan (Arif, 2017). Pengembangan kurikulum dengan pendekatan multikultural dapat dilakukan berdasarkan langkahlangkah berikut (Mansur, 2016);

1. Mengubah filosofis kurikulum dari yang penerapannya seragam kepada filosofis yang lebih di klasifikasikan dengan penyesuaian terhadap tujuan, misi, dan fungsi setiap jenjang pendidikan dan unit pendidikan.

2. Teori kurikulum tentang konten (curriculum content), harus berubah dari teori yang mengartikan konten sebagai aspek substantif yang berisikan fakta, teori, generalisasi ke pengertian yang mencakup nilai moral, prosedur, proses dan ketrampilan (skills).

3. Teori belajar yang digunakan dalam kurikulum masa depan dengan berpacu terhadap pada keragaman sosial, budaya, ekonomi, dan politik tidak boleh hanya mendasarkan diri pada teori psikologi belajar yang hanya menempatkan siswa sebagai makhluk sosial, sebagai anggota aktif masyarakat, bangsa, dan dunia yang harus disatukan ideologinya oleh institusi pendidikan.

4. Proses belajar yang dikembangkan untuk siswa harus didasari dengan proses yang memiliki tingkat isomorphisme yang tinggi dengan kenyataan sosial.

Pada pendidikan Islam berbasis multikultural terdapat nilai-nilai yang terkandung di dalamnya, meliputi: Nilai Andragogi; Nilai Perdamaian; Nilai Inklusivisme; Nilai Kearifan; Nilai Toleransi; Nilai Humanisme; Nilai Kebebasan. Nilai-nilai tersebut harus mampu dibumikan di dalam dunia pendidikan, sehingga lahirlah rasa saling menghargai anatar satu dengan yang lainnya dan akan tumbuh sikap mampu dalam menerima perbedaan yang merupakan suatu kekayaan yang harus dipupuk dengan baik, bukan menimbulkan persengketaan sehingga mampu hidup secara berdampingan dalam perbedaan dan kedamaian. Diharapkan dengan berkembangnya Pendidikan Islam berbasis multikultural, kurikulum mampu membawa output pendidikan memahami tentang ke-bhineka tunggal 
ikaan, mengakui dan menghargai adanya perbedaan dalam kesetaraan baik gender, ras, suku, budaya, bahasa, dan agama, serta kurikulum yang mampu memenuhi kebutuhan dalam pasar lokal, nasional dan global.

Guru agama merupakan aktor utama dalam menginternalisasikan nilai-nilai keberagaman yang inklusif dan moderat di sekolah maupun madrasah. Peran guru agama dalam hal ini antara lain: Pertama, seorang guru harus mampu untuk bersikap adil dan demokratis, artinya dalam segala tingkah lakunya, baik sikap maupun perkataannya tidak diskriminatif (bersikap tidak adil atau menyinggung) terhadap murid-murid penganut agama yang berbeda dengan agama yang dianut oleh gurunya. Kedua, guru agama sebaiknya memiliki rasa kepedulian yang tinggi terhadap kejadiankejadian tertentu yang ada kaitannya dengan agama. Seperti halnya kasus bom yang dilakukan oleh Amrozi di bali. Tugas guru ialah menyampaikan keprihatinannya bahwa janagan sampai hal seperti itu kembali terjadi. Karena seluruh agama yang ada melarang adanya tindak kekerasan dalam bentuk apapun, apalagi sampai menghilangkan beribu-ribu nyawa manusia. Kekerasan hanya akan memicu masalah-masalah baru. Guru sebaiknya menjelaskan bahwa agama mengajarkan kedamaian dan kesejahteraan umat. Jika terdapat perbedaan anatar kelompok, ras, atau golongan sebaiknya diselesaikan secara baik-baik dengan cara musyawarah. Dengan menerapkan pendidikan agama berbasis multikultural di sekolah maupun dalam dunia pendidikan diyakini mampu menjadi solusi nyata bagi terjadinya konflik dan disharmonisasi yang kerap terjadi di lingkungan masyarakat Indonesia yang beraneka ragam merupakan upaya preventif bagi peserta didik dalam menghadapi realitas sosial-budaya di era globalisasi.

\section{Catatan Akhir}

Berdasarkan pembahasan di atas, dapat ditarik kesimpulan bahwa, perlu disadari bersama dalam menanggulangi faham radikalisme agama yang sudah berada di depan mata bukanlah pekerjaan yang mudah seperti halnya membalikkan telapak tangan. 
Perlu dukungan yang erat dari berbagai elemen pendidikan seperti guru, kepala sekolah, waka kurikulum, orang tua, peserta didik. Jika ditemukan pihak yang menganut paham radikalisme bukanlah dengan cara kita mengasingkannya tetapi menjadi tanggung jawab pihak sekolah untuk merangkul dan menamkan nilai Pendidikan Agama Islam yang berbasis multikultural.

Dapat dipahami bersama bahwa nilai-nilai yang terkandung dalam pendidikan multikutural menjarakan adanya penghormatan dan penghargaan setinggi-tingginya terhadap harkat dan martabat manusia. Mampu menerima berbagai perbedaan sebagai suatu kewajaran dan dibutuhkan sikap toleransi agar kita bisa hidup berdampingan secara damai tanpa melihat unsur yang berbeda antar kelompok satu dengan lainnya. Menjadi tanggung jawab besar guru PAI di sekolah dalam mencanangkan konsep nilai yang ada pada pendidikan multikultural sehingga peserta didik mampu belajar hidup dari perbedaan, membangun sikap saling percaya, memelihara sikap saling penegertian, menjunjung sikap saling menghargai, terbuka dalam berpikir, dan rekonsiliasi nirkekerasan

\section{Daftar Pustaka}

Arif, M. 2017. Deradikalisasi Islam Melalui. Jurnal Akademika, 22 (1), $51-75$.

Baharun, H., \& Awwaliyah, R. 2017. Pendidikan Multikultural dalam Menanggulangi Narasi Islamisme di Indonesia. Jurnal Pendidikan Agama Islam (Journal of Islamic Education Studies), 5(2), 224-243.

Baharun, H., \& Mundiri, A. 2011. Metodologi Studi Islam: Percikan Pemikiran Tokoh Dalam Membumikan Agama. Jogjakarta: ArRuzz Media.

Deny Setiawan, B. K. A. 2016. Membangun Pemahaman dan Multiagama Guna Menangkal Radikalisme di Aceh Singkil. AlUlum: Jurnal Studi Islam, 16(2), 348-367.

Harto, K. 2014. Agama Islam Berbasis Multikultural Kasinyo Harto. Jurnal Al-Tabrir, 14(2), 411-431. 
Hasan Baharun, S. A. 2018. Curriculum Development Throught Creative Lesson Plan. Cendikia, 16(1), 41-62.

Hasan, S. Marliana. 2013. Anatomi Kurikulum Pendidikan Agama Islam Di Sekolah. Jurnal Al-Ibrah, 2(1), 60-87.

Irsyad, M. 2016. Pengembangan Kurikulum Pendidikan Agama Islam di Madrasah (Studi Atas Pemikiran Muhaimin). Jurnal Iqra', 2(1), 2527-4449.

Islam, S., Baharun, H., Muali, C., Ghufron, M. I., \& Bali, M. M. E. I. 2018. To Boost Students 'Motivation and Achievement through Blended Learning. Journal of Physics: Conference Series, 111.

Katni, O. M. 2015. Pengembangan Kurikulum PAI. Surabaya: Kopertais IV Press.

Khuzaimah. 2017. Paradigma Pengembangan Kurikulum Pendidikan Agama Islam di Sekolah ( Analisis berbagai Kritik terhadap PAI ). Jurnal Kependidikan, V(1), 105-118.

Kisbiyanto. 2016. Manajemen Kurikulum Dalam Perspektif AntiRadikalisme. Jurnal Addin, 10(1), 181-206.

Mansur, R. 2016. Pengembangan Kurikulum Pendidikan Agama Islam Multikultural (Suatu Prinsip-prinsip Pengembangan). Kependidikan Dan Keislaman, 10(2).

Marzuki, M. B. 2008. Falsafah Kurikulum dalam Pendidikan Islam. Jurnal Hunafa, 5(1), 23-26.

Muali, C., Islam, S., \& Bali, M. M. E. I. 2018. Free Online Learning Based On Rich Internet Applications; The Experimentation Of Critical Thinking About Student Learning Style. Journal of Physics: Conference Series, 1114, 1-6.

Munip, A. 2012. Menangkal Radikalisme Agama di Sekolah. Jurnal Pendidikan Islam, I(2), 159-181. https://doi.org/10.14421 /jpi.2012.12.159-181

Nurmadiah. 2014. Kurikulum Pendidikan Agama Islam. Jurnal AlAfkar, 3(2).

Ramayulis. 2006. Ilmu Pendidikan Islam. Jakarta: Kalam Mulia. 
Roscahyo, A., \& Prijati. 2013. Pengaruh Gaya Kepemimpinan Terhadap Kinerja Karyawan Pada Rumah Sakit Siti Khodijah Sidoarjo. Ilmu Dan Riset Manajemen, 2(12), 1-16.

Subhi, A. 2016. Konsep Dasar, Komponen dan Filosofi Kurikulum PAI. Jurnal Qathruna, 3(1), 117-134.

Thohir, M. 2015. Radikalisme Versus Pendidikan Agama Menggali Akar Radikalisme Dari Kekerasan Terhadap Anak Atas Nama Pendidikan Agama Pendahuluan Kendati Indonesia telah Meratifikasi konvensi hak Anak dari Perserikatan BangsaBangsa ( PBB ) selama 25 tahun, namun ke- ke. Jurnal Nadwa Pendidikan Islam, 9(2), 167-182.

Universitas, H., Semarang, N., Hukum, F., Semarang, U. N., Tengah, J., \& Semarang, U. N. 2017. Islam Tidak Radikalisme dan Terorisme, 3, 197-218. 